ACTA THERIOLOGICA

Vol. 23, 23: $371-380,1978$

\title{
Minimum and Maximum Metabolic Rates of Sorex sinuosus
}

\author{
James R. NEWMAN \& Robert L. RUDD
}

\begin{abstract}
Newman J.R. \& Rudd R. L., 1978: Minimum and maximum metabolic rates of Sorex sinuosus. Acta theriol., 23, 23: 371-380 [With 1 Fig. \& 5 Tables].

The minimal and maximal metabolic rates of Sorex sinuosus are similar to other species of shrews. These metabolic rates showed considerable variability depending upon the season, nutritional state, sex behavior and time of day. The average minimal metabolic rate at $20^{\circ} \mathrm{C}$ is $4.5 \mathrm{kcal} /$ day while the average maximum metabolic rate at $20^{\circ} \mathrm{C}$ is $6.0 \mathrm{kcal} / \mathrm{day}$. Only under extreme fasting conditions did minimal metabolic rates approach predicted basal values for small mammals. The constantly active nature of shrews contributes to the high metabolic rates observed in S. sinuosus.

[Environ. Sci. Engineer., Inc. P.O. Box 13454, Univ. Stat., Gainesville, Florida 32605 (JRN) and Dept. Zool., Univ. Calif., Davis, California 95616 (RLR)].
\end{abstract}

\section{INTRODUCTION}

Opinion is divided as to why the observed "basal " metabolic rates of shrews are higher than the predicted basal metabolic rates derived from $\mathrm{K}$ le i be r's (1967) allometric equation for mammals of similar size. One group of investigators believes that these observed high metabolic rates are characteristic of shrews (Pearson, 1948; G ę bc zyński, 1965, 1971a; Gębczyńska \& G ębczyński, 1965; P oczopko, 1971; V o g e 1, 1976). Vog e 1 (1976) compared the metabolism of 13 species of shrews and concluded that only the tribe Soricini have a uniquely higher metabolic rate. The subfamily Crocidurinae is characterized by relatively low metabolic rates. The tribes Neomyini and Blarinini have intermediate metabolic rates. Other investigators attribute these observed high values to experimental conditions such as SDA and activity (M o r ris on, et al., 1959; Hawkins et al., 1960; Buckner, 1964; Martinsen, 1969; P la t t, 1974).

Several factors are known to significantly affect the metabolism of small mammals including size, shape, sex, reproductive condition, ciradian variation, season, activity and temperature (G e s s a m a n, 1973; Grodziński \& W under, 1975). Detailed studies on the metabolism and factors affecting the metabolism of the genus of Sorex have been 
conducted on five species: S. araneus (G ę b c z y ńs k i, 1965); S. arcticus; S. cinereus (B u c k n er, 1964); S. minutus (G ę b c z y ń s k i, 1971b). Additional studies on other species are needed to further explain the metabolic uniqueness of shrews (Poczopko, 1971). The objectives of this study were to measure the minimum and maximum metabolic rates of $S$. sinuosus and to determine some factors influencing the metabolic rate of this species.

\section{MATERIAL AND METHODS}

Sorex sinuosus is a small insectivore which occurs in the northern salt marshes of San Pablo Bay and Suisun Bay, of California (R udd, 1955). At birth S. sinuosus weighs about 0.5 grams and grows to an average weight of 4.5 grams. Reproductıvely active shrews may weigh as much as 7 grams ( $\mathrm{R} \mathrm{udd}$, 1955). Reproduc. tive activity starts in late February, reaches a peak in May, and declines sharply in early June (J ohnston \& Rudd, 1957). S. sinuosus has a life expectancy of less than one year although a small number of individuals do survive through the second year. There is a turnover in age classes of adults born the previous year to adults born in the calendar year during the summer. At this time three age classes can be identified: juveniles, young adults, and old adults ( $\mathrm{R} \mathrm{udd} \mathrm{1955).} \mathrm{Because}$ of the defined breeding season and seasonal change in age classes, three seascns were recognized for analysis: spring (March, April, May, and June), late summer (July, August, September, and October), and winter (November, December, January, and February). S. sinuosus was captured using Sherman live traps $(22 \times 8 \times 8 \mathrm{~cm})$ during 1967 to 1970 . Captured shrews were maintained in the laboratory under the normal lighting regime of the salt marsh and fed a mixture of beef brains and Purina Cat Chow (Registered trademark). The animal room approximated the normal temperature regime of the salt marshes to within $5^{\circ} \mathrm{C}$.

Oxygen consumption was measured in a metabolism chamber using a Beckman model F-3 paramagnetic oxygen analyzer with a span of 19-21 percent oxygen in an open-circuit system. The millivolt output of the analyzer was continuously monitored on a Honeywell Stripchart recorder. The animals were supplied with carbon dioxide-free air and oxygen analysis was also performed on carbon dioxidefree air. Oxygen consumption values were calculated according to the formula of De pocas \& Hart (1957) for open-circuit systems. This procedure has been found to produce accurate results (H ill, 1972).

The metabolism chamber was a 0.33 liter glass chamber. The floor of the chamber was wired with micro-switches which detected any locomotor activity. This activity was recorded simultaneously with oxygen consumption on an Esterline-Angus Event recorder. By comparing oxygen consumption values with activity recordings the metabolic rates during periods of activity and inactivity could be determined. During the experiments the metabolism chamber was submerged in a constant temperature water bath kept at $20^{\circ} \mathrm{C}$. Food and water were provided ad libitum during each experiment. Metabolic measurements were made within three weeks of capture. The minimal metabolism was calculated to be the mean of the lowest oxygen consumption values observed in each 15-minute interval through 24 hours. Maximum metabolism was the mean of the highest values observed in each 15-minute interval through 24 hours. 


\section{RESULTS}

The metabolic rate of $S$. sinuosus exhibited considerable variability depending upon the season, nutritional state, behavior and time of day. The minimal daily metabolic rate at $20^{\circ} \mathrm{C}$ ranged from $3.3 \pm 1.2 \mathrm{kcal} /$ day in the winter to $6.9 \pm 1.2 \mathrm{kcal}$ per day in the spring (Table 1).

Comparison of seasonal metabolic rates reveal a significant decline $\left[t_{(.01,(44)}=3.214\right]$ in minimal daily metabolic rates from late summer to winter. There is a significant increase $\left[t_{(.01)(31)}=3.645\right]$ in the metabolic

Table 1

Comparison of the seasonal minimal daily metabolic rate at $20^{\circ} \mathrm{C}$ of $\mathrm{S}$. sinuosus with predicted basal metabolic rates.

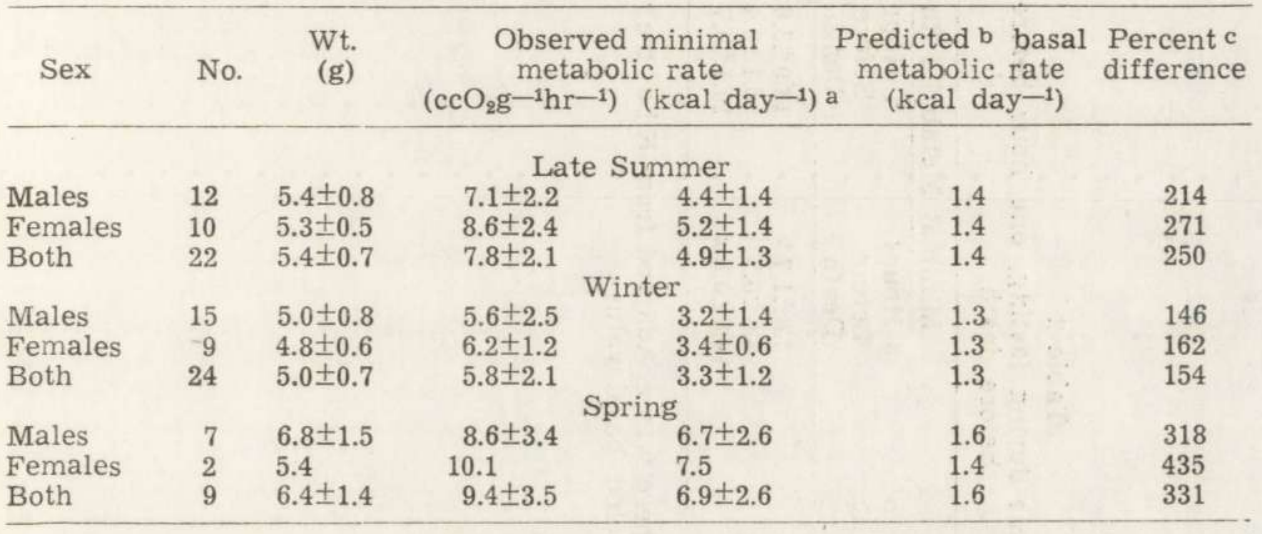

a kcal day ${ }^{-1}=\mathrm{ccO}_{2} \mathrm{~g}^{-1} \mathrm{hr}^{-1} \times 24 \mathrm{hr} \times \mathrm{wt}^{-\mathrm{g})} \times 4.8 \div 1000$. K le i be r (1961).

b $\mathrm{kcal} /$ day $=69 \mathrm{~W} .75 \pm 1.2 \mathrm{kcal}$ where $W=\mathrm{kg}$. K l e i b e r (1961).

c (Minimal metabolic rate-predicted basal metabolic rate/predicted basal metabolic rate) $\times 100$.

rates from winter to spring. No significant differences existed between the seasonal body weights of these experimental animals. Fasting metabolic rates were observed in three shrews during experiments in which food was deprived (Table 2). All experiments ended in the death of the animal with measurement times lasting from 5 to 23 hours. Fasting animals lost between 8 and $10 \%$ of their body weights. The minimal metabolism observed three hours before death (considered post-absorptive) was significantly greater than the predicted basal values. These values were 3 to 6 times greater than predicted basal values. At one hour before death only one animal showed a metabolic rate significantly higher than predicted basal values. At 15 minutes before death the fasting metabolic rates of the three shrews were not significantly different from the predicted basal values. 


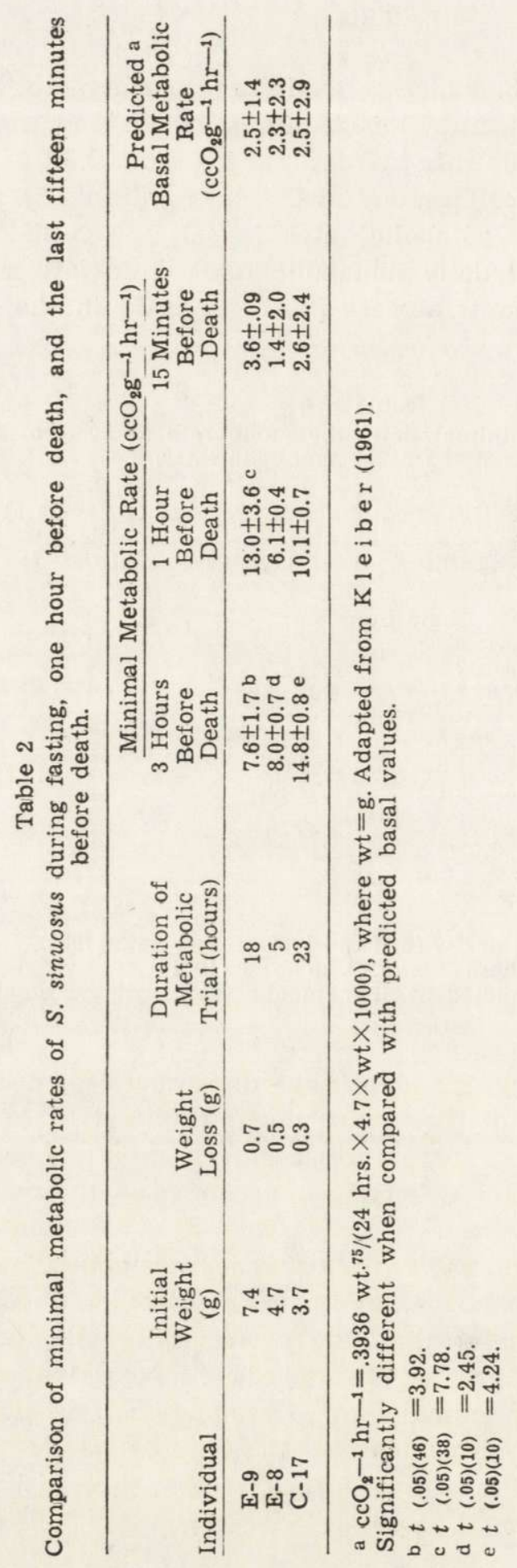


Females had an average metabolic rate that was $15 \%$ higher than males (Table 1). Although this difference was not significant, the higher metabolic rates of females was observed in each season. Females showed a greater variation in metabolic rate than males from season to season.

Comparison of the minimal metabolic rates of juveniles, young adults, and old adults, showed that juveniles had the highest metabolism, and old adults the lowest. However, this variation was not statistically significant and appears to be weight related (Table 3 ). One very old female, Table 3

Comparison of the minimal metabolic rates of various age classes of $S$. sinuosus in late summer.

\begin{tabular}{lccc}
\hline & Juveniles & Young Adults & Old Adults \\
\hline Number & 7 & 11 & 8 \\
Body weight (g) & $3.7 \pm 0.3$ & $4.9 \pm 0.5$ & $5.7 \pm 0.6$ \\
Minimal metabolic rate $\left(\mathrm{cc}_{2} \mathrm{~g}^{-1} \mathrm{hr}-1\right)$ & $9.5 \pm 5.7$ & $8.5 \pm 2.3$ & $6.6 \pm 1.6$ \\
\hline
\end{tabular}

Table 4

Comparison of mean minimal and maximum metabolic rates for late summer, winter, and spring.

\begin{tabular}{lccc}
\hline & Late Summer & Winter & Spring \\
\hline Number & 22 & 24 & 9 \\
Minimal metabolic rate $\left(\mathrm{c} \mathrm{O}_{2} \mathrm{~g}^{-1} \mathrm{hr}^{-1}\right)$ & $7.8 \pm 2.1 \mathrm{~b}$ & $5.8 \pm 2.1 \mathrm{c}$ & $9.4 \pm 3.5$ \\
Maximum metabolic rate $\left(\mathrm{cc} \mathrm{O}_{2} \mathrm{~g}^{-1} \mathrm{hr}^{-1}\right)$ & $9.5 \pm 2.1 \mathrm{~b}$ & $8.8 \pm 2.1 \mathrm{c}$ & $12.4 \pm 3.3$ \\
Percent a difference & 22 & 52 & 32 \\
\hline
\end{tabular}

a (max. met. rate $-\min$. met. rate/min. met. rate) $\times 100$.

b Significantly different; $t$ (.02) (42) $=2.464$.

c Significantly different; $t(.001)(46)=4.784$.

approximately 22 months old, had a metabolic rate similar to the rest of the population sampled.

Activity was recorded in every hour during the metabolic experiments and was a major factor in raising metabolic rate (Table 4). The maximum daily metabolic rates corresponding to periods of activity were significantly higher (22 to $52 \%$ ) than minimal daily metabolic rates. Although maximum daily metabolic rates of spring were $32 \%$ higher than minimal daily metabolic rates of the spring, they were not significantly different $\left[t_{(.05)(16)}=1.858\right]$. Significant differences were observed between the diurnal and nocturnal metabolic rates of winter and spring individuals (Table 5 ). Individuals from the winter had a slightly greater diurnal metabolic rate while individuals from the spring had a $24 \%$ greater nocturnal metabolic rate. There was no significant difference between the diurnal and nocturnal metabolism of late summer. 


\section{DISCUSSION}

Minimal metabolic rates of Sorex sinuosus are similar to the minimal metabolic rates observed in other species of shrews, especially the genus Sorex (Fig. 1). V o g e l (1976) derived an allometric equation for the minimal metabolism of Soricinae $\left(M=82.6 W^{0.53}\right.$, where $M$ equals cal./hr. and $W$ equals grams). It best describes the late summer minimal metabolism of $S$. sinuosus. The observed minimal metabolism of spring and winter animals are respectively higher and lower than the metabolism described

Table 5

Comparison of the mean diurnal metabolic rate with the mean nocturnal metabolic rate and night/day ratios (N/D) for late summer, winter and spring.

\begin{tabular}{lccc}
\hline & Late Summer & Winter & Spring \\
\hline $\begin{array}{l}\text { Number } \\
\text { Mean diurnal metabolic rate }\end{array}$ & 9 & 24 & 15 \\
$\quad\left(\mathrm{cc}_{2} \mathrm{~g}^{-1} \mathrm{hr}^{-1}\right)$ & $9.6 \pm 0.4$ & $6.8 \pm 0.6 \mathrm{a}$ & $10.2 \pm 2.1 \mathrm{~b}$ \\
$\begin{array}{l}\text { Mean nocturnal metabolic rate } \\
\quad\left(\mathrm{cc}_{2} \mathrm{~g}^{-1} \mathrm{hr}^{-1}\right)\end{array}$ & $9.7 \pm 0.3$ & $6.3 \pm 0.3 \mathrm{a}$ & $12.7 \pm 1.6 \mathrm{~b}$ \\
$\mathrm{~N} / \mathrm{D} \mathrm{ratio}$ & 1.02 & 0.93 & 1.24 \\
\hline
\end{tabular}

a Significantly different; $t(.05)(22)=3.395$.

b Significantly different; $t$ (.01) (13) $=3.070$.

by this allometric relationship. At thermal neutrality, the minimal metabolic rates in other species of shrews are considerably higher than predicted basal values (M orris on et al., 1959; H aw k in s et al., 1960; Gębczyńska \& Gębczyński, 1965). Minimal metabolic rates measured under post-absorptive conditions in S. sinuosus, Cryptotis par$v a$ (Pf e if f e r \& G a s s, op. cit.), S. araneus, S. minutus, and Neomys fodiens (G ę bczyński, 1971b) were found to be significantly higher than predicted. Only under extreme fasting conditons resulting in death of the animal did the observed metabolic rates of $S$. minutus and $S$. araneus significantly drop to near »basal " levels. This lowering of metabolism was associated with a reduction in activity of the fasting shrews (G ę bczyński, 1971b). S. sinuosus showed the same response to extreme fasting. Seasonal variation in the metabolic rates of shrews is common. Winter is a time of energy reduction in Neomys fodiens ( $\mathrm{G}$ ę bc z yńska \& Gę b cz yński, 1965), S. araneus and $S$. minutus (Gę bc z y ński, 1965). A $34 \%$ decline in the metabolic rate from summer to winter is observed in $S$. sinuosus (Table 1).

In European shrews, a reduction in body size and organ weight also occurs during the winter ( $\mathrm{Dehnel}, 1949$; P u ce k, 1965). An analysis of the body weights of $S$. sinuosus revealed a similar seasonal drop in 
body weights. The average body weight for $S$. sinuosus is $3.9 \pm 0.1$ grams $(n=43)$ in the winter compared to $4.3 \pm 0.1$ grams $(n=50)$ for the summer and $5.9 \pm 0.2$ grams $(n=120)$ for the spring. This seasonal reduction in metabolic rates and body weights of shrews is hypothesized as an adaptation for physiological conservation during periods of the year with high energy demands (G ę bc zyński, 1965; Mezhzherin, 1969).

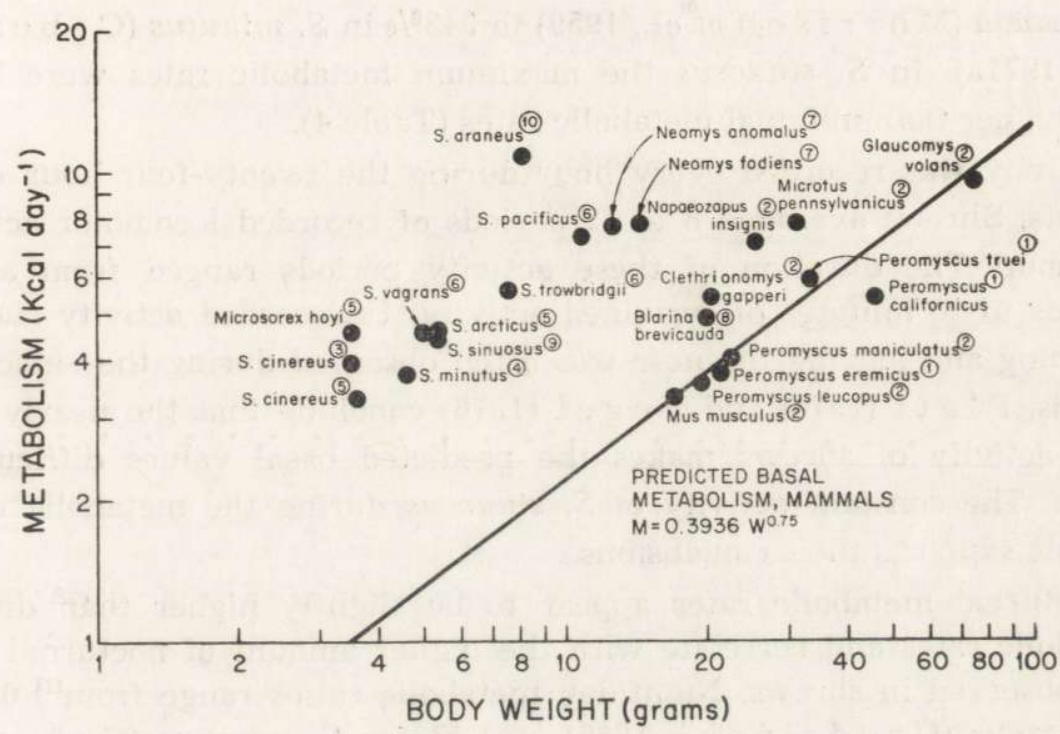

Fig. 1. Comparison of the observed minimal metabolic rates of shrews with other small nammals: 1-McNab \& Morrison, 1963; 2-Pearson, 1947; 3-Morrison et al., 1959; 4-Gębczyński, 1971a; 5-Buckner, 1964; 6-Pearson, 1948; 7-Gębczyńska \& Gębczyński, 1965; 8-Martinson; 1969; 9-Author; 10-Gębczyński, 1965.

An increase in spring metabolic rates is observed in $N$. fodiens ( $\mathrm{G}$ ę bc zyńska \& Gębczyński, 1965) and S. araneus (Gębczyński, 1965). S. sinuosus shows a $67 \%$ increase in metabolic rate from winter to summer. These increases in energy expenditure of shrews are associated with increases in body size resulting in part from reproductive maturation (J ohnston \& R udd, 1955; R udd, 1955; P u cek, 1965; Brown, 1974) and increased activity associated with the reproduction (B u ckner, 1969; Croin-Michielsen, 1966; New man, 1976). In the autumn metabolic rates of $S$. araneus and $S$. minutus are intermediate between the metabolic rates of spring and winter (G ę b c z y n s ki, $1965 ; 1971)$. A similar pattern exists in $S$. sinuosus for late summer metabolic rates (Tab. 1). 
The metabolic sensitivity of shrews to activity can be seen in the differences between the differences in maximum (active) and minimum (resting) metabolic rates. Shrews are active twenty-four hours a day with greatest amount of activity occurring at night (H a milto n, 1940; Clothier, 1955; C r ow crof t, 1957; Ingles, 1960; S hillito, 1963; B uchalczyk, 1972; Newman, 1976). The difference in maximum and minimum metabolic rates of shrews range from $28 \%$ in Blarina brevicauda (M or r i s o n et al., 1959) to $343 \%$ in S. minutus (G ę b c z y ń$\mathrm{ski}, 1971 \mathrm{a})$. In $S$. sinuosus the maximum metabolic rates were 20 to $52 \%$ higher than minimal metabolic rates (Table 4).

Activity was recorded every hour during the twenty-four hour experiments. Shrews averaged 8 to 12 periods of recorded locomotor activity per hour. The duration of these activity periods ranged from a few seconds to 10 minutes of sustained activity. Unrecorded activity such as twitching and moving the nose was often observed during the "inactive" periods. P la t t (1974) and V o gel (1976) conclude that the nearly constant activity of shrews makes the predicted basal values difficult to obtain. The constant activity of $S$. sinuosus during the metabolic experiments supports their conclusions.

Nocturnal metabolic rates appear to be slightly higher than diurnal metabolic rates and correlate with the higher amount of nocturnal activity observed in shrews. Night/day metabolic ratios range from 1.04 for S. cinereus (Grodzińs ki, 1965) to 1.17 for $S$. minutus (G ę b c zy ń$\mathrm{ski}, 1971 \mathrm{a})$. S. sinuosus showed a similar pattern during the spring and late summer with night/day ratios of 1.24 and 1.02, respectively. During the winter, diurnal energy expenditure is slightly higher (Table 5). Seasonal variation in the night/day ratios is also observed in $S$. araneus (G ę b c z y ński, 1965).

Investigations into the metabolic patterns of $S$. sinuosus and other species of shrews reveal a number of significant factors affecting their metabolic rates. Efforts at developing daily and annual energy budget for shrews should account for these factors, especially seasonal and behavioral influences.

Acknowledgements: We would also like to thank the late. Dr Max Kleiber, University of California (Davis), for his guidance during the study. This research was partially supported by Chancellor's Patent Fund D. G. 132 and NSF Grants G.B. 6392 and G.B. 15916. In addition, we thank Word Processing Center, Environmental Science and Engineering, Inc. (Gainesville, Florida), for typing the manuscript, and Joy Dabney, Western Washington University (Bellingham, Washington), for the art work. 


\section{REFERENCES}

1. Brown R. J., Sexual dimorphism in the pelvic girdle of the ornate shrew, Sorex ornatus. Wasmann J. Biol. 32: 99-104.

2. Buchalczyk A., 1972: Seasonal variation in the activity of shrews. Acta theriol., 17: 221-242.

3. Buckner C. H., 1964: Metabolism, food capacity and feeding behavior in four species of shrews. Canad. J. Zool. 42: 259-279.

4. Buckner C. H., 1969: Some aspects of the population ecc ogy of the common shrew, Sorex araneus near Oxford, England. J. Mammal. 50: 326-332.

5. Clothier R. R., 1955: Contributions to the life history of Sorex vagrans in Montana. J. Mammal. 36: 214-221.

6. C roin-Michiels on N. C., 1966: Intraspecific and interspecific competition in the shrews Sorex araneus $L$. and $S$. minutus $L$. Archs neerl. Zool., 17: 73-174 .

7. Crowcroft P., 1957: The life of the shrew. Reinhart: 1-166. London.

8. Dehnel A., 1949: Studies on the genus Sorex L. Ann. Univ. M. Curie-Skłodowska, C. 4: 17-102.

9. Depocas F. \& Hart J. S., 1957: Use of the Pauling Oxygen Analyser for measurement of oxygen consumption of animals in open-circuit systems and in a short-lag, closed-circuit apparatus. J. Appl. Physiol. 10: 338-392.

10. Gębczyńska Z. \& Gębczyński M., 1965: Oxygen consumption in two species of water shrews. Acta theriol. 10: 209-214.

11. Gębczyński M., 1965: Seasonal and age changes in the metabolism and activity of Sorex araneus Linnaeus, 1758. Acta theriol. 10: 303-331.

12. Gębczynski M., 1971a: The rate of metabolism of the lesser shrew. Acta theriol. 16: 329-339.

13. Gę b czyński M. 1971b: Oxygen consumption in starving shrews. Acta theriol. 16: $288-292$.

14. Gessaman J.A. 1973: Ecological energetics of hameotherms: A view compatible with ecological modeling. Utah State University Monographs Series, 20: $1-155$.

15. Grodziński W., 1965: Bionergetics of small mammals from Alaskan taiga forest. Lynx, 6: $51-55$.

16. Hamilton W. J., Jr. 1940: The biology of the smoky shrew (Sorex fumeus fumeus Miller). J. Mammal. 25: 473-492.

17. Hawkins A. E., Jewell P. A., \& Tomlinson G., 1960: The metabolism of some British shrews. Proc. zool. Soc. Lond., 135: 99-103.

18. Hill R. W. 1972. Determination of oxygen consumption by use of the paramagnetic oxygen analyser. J. Appl. Physiol. 33: 261-263.

19. Ingles L. G., 1960: A quantitative study of the activity of the dusky shrew (Sorex vagrans obscurus). Ecology, 42: 655-660.

20. Johnston R. F. \& R udd R. L., 1957: Breeding of the salt marsh shrew. J. Mammal. 38: 157-163.

21. Kle i ber M. 1961. Fire of life. John Wiley \& Sons: 1-454. New York.

22. Martinsen D. L., 1969: Energetics and activity patterns of short-tailed shrews (Blarina) on restricted diets. Ecology, 50. 505-510.

23. $\mathrm{McN}$ a b B. K. \& Morris on P., 1963: Body temperature and metabolism in subspecies of Peromyscus from arid and mesic environments. Ecology Mono., 33: $63-82$. 
24. Mezhzherin V. A., 1969: Energetics of populations and evolution of the shrews (Sorex, Insectivora, Mammalia). [In: K. Petrusewicz \& L. Ryszkowski (Eds), «Energy Flow Through Small Mammals Populations»]. PWN-Polish Scientific Publishers: 149-156. Warszawa.

25. Morrison P., Ryser F. A. \& Dawe A., 1959: Studies on the physiology of the masked shrew, Sorex cinereus. Physiol. Zool. 32: 256-271.

26. Newman J. R. 1976. Population dynamics of the Wandering Shrew Sorex vagrans. Wasmann J. Biol. 34: 235-250.

27. Pears on O.P., 1947: The rate of metabolism of some small mammals. Ecology, 28: $128-145$.

28. Pears on O. P., 1948: Metabolism of small mammals with remarks on the lower limit of mammalian size. Science 108: 44.

29. Pfe iffer C. J. \& G a s G. H. 1962. Oxygen consumption in the small shorttailed shrew (Cryptotis parva). Trans. Ill. State Acad. Sci. 55: 130-132.

30. Pla t t W. J., 1974: Metabolic rates of short-tailed shrews. Physiol. Zool. 47: 75-90.

31. Poczopko P. 1971. Metabolic levels in adult homeotherms. Acta theriol. 16: $1-21$.

32. Pucek Z. 1965. Seasonal and age changes in the weight of internal organs of shrews. Acta theriol. 10: $369-498$.

33. R u d d R. L. 1955. Age, sex, and weight comparisons in three species of shrews. J. Mammal. 36: 323-339.

34. Shillito J. F. 1963. Field observations on the growth, reproduction and activity of a woodland population of the common shrew Sorex araneus L. Proc. Zool. Soc. Lond., 140: 94-144.

35. Vogel P. 1976. Energy consumption of European and African shrews. Acta theriol. 21: 207-215.

Accepted, January 4, 1978.

James R. NEWMAN \& Robert L. RUDD

\section{TEMPO METABOLIZMU MINIMALNEGO I MAKSYMALNEGO U SOREX SINUOSUS}

Zbadano minimalne i maksymalne tempo metabolizmu u Sorex sinuosus. Obydwa te parametry charakteryzują się dużą zmiennością i zależą od sezonu, płci, wieku, okresu doby i stopnia najedzenia. Minimalne, średnie tempo metabolizmu, mierzone przy $20^{\circ} \mathrm{C}$ wynosi $4.5 \mathrm{kcal} /$ dobę, maksymalne, mierzone w tej samej temperaturze - $6.0 \mathrm{kcal} /$ dobę (Tabela 1 ). Samice mają średnio o $15 \%$ wyższy metabolizm niż samce. W zależności od sezonu tempo metabolizmu ulega istotnym zmianom: obniżeniu $w$ okresie od końca lata do zimy i podwyższeniu od zimy do wiosny (Tabela 4).Tylko głodzone ryjówki, tuż przed śmiercią głodową, wykazują niższy metabolizm minimalny niż oszacowany dla nich metabolizm podstawowy (Tabela 2).

Najwyższym tempem metabolizmu charakteryzują się osobniki młode a najniższym stare (Tabela 3). Ustalono, że największy wplyw na tempo metabolizmu wywiera aktywność ryjówek (Tabela 4) - stąd maksymalne dobowe tempo metabolizmu połączone $\mathrm{z}$ dużą aktywnością ruchową jest do $55 \%$ wyższe niż minimalne. Obserwowano również istotne różnice w tempie metabolizmu dziennego i nocnego u zwierząt w różnych sezonach (Tabela 5). 